\title{
RESPON PENGGUNA LULUSAN JURUSAN PENDIDIKAN AGAMA ISLAMI FAKULTAS TARBIYAH DAN KEGURUAN UIN ALAUDDIN MAKASSAR: Studi Kasus Pada Kota Makassar
}

\author{
Usman \\ Fakultas Tarbiyah dan Keguruan \\ Universitas Islam Negeri Alauddin Makassar \\ Jl. H. M. Yasin Limpo No. 36 Samata, Gowa \\ Email: uma_aandinda@yahoo.co.id
}

\begin{abstract}
This paper is the result of the author's research which is compiled into a journal with the main problem of how the user response is graduated from the Department of Islamic Religious Education of Faculty of Tarbiyah and Teacher Training UIN Alauddin in Makassar City in terms of professionalism, information, ability to communicate, teamwork, and ability to do self-development. Sources of data as respondents consist of elements of schools and madrassas in Makassar City who have PAI subject teachers or clumps of PAI subjects who have an undergraduate education background in the Department of PAI Faculty of Tarbiyah and Teacher Training UIN Alauddin Makassar. School and madrasah in question amounted to 15 schools / madrasah with the number of teachers assessed by the principal / madrasah amounted to 40 people. The results showed that the attitude of professionalism of alumni of Islamic Education Department Faculty of Tarbiyah and Teacher Training UIN Alauddin Makassar included in very good category with value 3,66; attitudes of integrity (ethics and morals) are included in the excellent category with a score of 3.74; abilities in the language fall into either category with a value of 2.70; ability to use information technology in learning activities included in good category with value 3,32; communication ability included in very good category with value 3,70; team cooperation ability included in very good category with value 3,61; and ability to do self-development included in good category with value 3,49.
\end{abstract}

Keywords: Response, Alumni User, PAI Alumni Competence

\section{LATAR BELAKANG}

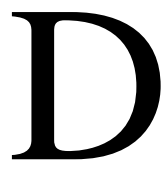
alam upaya perbaikan mutu pendidikan di perguruan tinggi agar dapat menghasilkan lulusan yang memiliki daya saing dan dapat berkiprah dalam pembangunan nasional maka salah satu indikator keberhasilan adalah aspek relevansi. Survey tanggapan pengguna lulusan merupakan pendekatan yang memungkinkan institusi pendidikan tinggi memperoleh informasi tentang kekurangan yang mungkin terjadi dalam proses pendidikan dan proses pembelajaran dan dapat merupakan dasar untuk perencanaan aktivitas untuk penyempurnaan mutu di masa yang akan datang. Upaya dalam perbaikan telah banyak dilakukan, baik di bidang akademik 
maupun non akademik. Upaya tersebut dimaksudkan untuk memperbaiki mutu lulusan sesuai tuntutan kekinian, seperti kompetensi lulusan PAI dalam mengajar di sekolah atau madrasah, menggunakan teknologi pembelajaran yang handal serta pengaruh globalisasi telekomunikasi informasi, dan lain sebagainya.

Lulusan yang memiliki kompetensi/kemampuan mengajar sesuai kebutuhan sekolah/madrasah, menggunakan TIK dalam pembelajaran dan memiliki daya bersaing di era global adalah lulusan yang memiliki berbagai jenis kompetensi mengikuti kebutuhan stakeholders. Dengan kemampuan yang dimiliki diharapkan lulusan dapat menjadi kader pemimpin bangsa di masa mendatang. Selain itu, para lulusan dapat juga diminta untuk menilai kondisi studi yang mereka alami selama mengikuti proses pendidikan dan pembelajaran.

Survey dalam bentuk tracer study sangat dibutuhkan oleh setiap perguruan tinggi termasuk Jurusan Pendidikan Agama Islam Fakultas Tarbiyah dan Keguruan UIN Alauddin Makassar, guna untuk mengetahui keberhasilan proses pendidikan dan pembelajaran yang telah dilakukan selama ini, baik pada mahasiswa program S1 reguler maupun program S1 peningkatan kualifikasi bagi guru madrasah dan sekolah.

Di samping itu, tuntutan penilaian kinerja program studi oleh Badan Akreditasi Nasional Perguruan Tinggi (BAN-PT) merupakan dasar pijakan pengembangan program kegiatan akademik. Salah satu butir dalam isian borang akreditasi ialah mengenai evaluasi kinerja lulusan oleh pihak pengguna lulusan.

Dengan demikian, penelitian dalam rangka perbaikan dan pengembangan Jurusan Pendidikan Agama Islam Fakultas Tarbiyah dan Keguruan UIN Alauddin Makassar sangat dibutuhkan. Masalah pokok dalam tulisan ini adalah bagaimana respon pengguna lulusan Jurusan Pendidikan Agama Islam Fakultas Tarbiyah dan Keguruan UIN Alauddin Makassar dengan fokus pada sikap profesionalisme alumni, kemampuan bahasa, kemampuan menggunakan teknologi informasi, kemampuan berkomunikasi, kemampuan kerjasama tim, dan kemampuan melakukan pengembangan diri.

\section{KAJIAN TEORETIS}

\section{A. Teori Respon}

Respon atau tanggapan adalah kesan-kesan yang dialami jika perangsan sudah tidak ada, jika proses pengamatan sudah berhenti, dan hanya tinggal kesan-kesan saja. Tanggapan ialah gambaran ingatan dari pengamatan (Kartono, 1990). Untuk mengetahui respon masyarakat dapat dilihat melalui persepsi, sikap, dan partisipasi. Respon pada prosesnya didahului sikap seseorang, karena sikap merupakan kecenderungan atau kesediaan seseorang untuk bertingkahlaku kalau ia menghadapi suatu ransangan tertentu.

Menurut Soekanto (1993: 48) respon sebagai perilaku merupakan konsekuensi dari perilaku yang sebelumnya sebagai tanggapan atau jawaban suatu persoalan atau masalah tertentu. Menurut paradigma definisi sosial Weber (dalam Ritzen, 2003: 76) tentang tindakan sosial, respon adalah tindakan yang penuh arti dari individu sepanjang tindakan 
itu memiliki makna subjektif bagi dirinya dan diarahkan pada orang lain. Tindakan sosial yang dimaksud dapat berupa tindakan yang bersifat membatin atau bersifat subjektif yang mungkin terjadi karena terpengaruh dari situasi atau juga dapat merupakan tindakan pengulangan dengan sengaja sebagai akibat dari pengaruh situasi serupa. Abidin (dalam Susanto, 1988: 51-57) memberikan pengertian respon adalah reaksi yang dilakukan seseorang terhadap rangsangan, atau perilaku yang dihadirkan rangsangan.

Respon muncul pada diri manusia melalui suatu reaksi dengan urutan yaitu: sementara, ragu-ragu, dan hati-hati yang dikenal dengan trial response, kemudian respon akan terpelihara jika organisme merasakan manfaat dari rangsangan yang datang. Susanto (1988: 73) mengatakan respon merupakan reaksi, artinya penerimaan atau penolakan, serta sikap terhadap apa yang disampaikan oleh komunikator dalam pesannya. Respon dapat dibedakan menjadi opini (pendapat) dan sikap, dimana pendapat atau opini adalah jawaban terbuka (overt response) terhadap suatu persoalan yang dinyatakan dengan katakata yang diucapkan atau tertulis. Sedangkan sikap merupakan reaksi yang tertutup (convert response) yang bersifat emosional dan pribadi, merupakan tendensi untuk memberikan reaksi yang sangat positif atau negatif terhadap orang-orang, obyek, atau situasi tertentu.

Harvey dan Smith (dalam Ahmadi, 1999: 164) mendefinisikan bahwa respon merupakan bentuk kesiapan dalam menentukan sikap baik dalam arti positif atau negatif terhadap obyek atau situasi.

Respon juga diartikan suatu tingkahlaku atau sikap yang berwujud baik sebelum pemahaman yang mendetail, penilaian, pengaruh atau penolakan, suka atau tidak serta pemanfaatan pada suatu fenomena tertentu. Menurut Louis Thursone, respon merupakan jumlah kecenderungan dan perasaan, kecurigaan dan prasangka, pra-pemahaman yang mendetail, ide-ide, rasa takut, ancaman dan keyakinan tentang suatu hal yang khusus. Pengertian tersebut dapat diketahui bahwa cara pengungkapan sikap dapat melalui pengaruh atau penolakan, penilaian, suka atau tidak suka, kepositifan atau kenegatifan suatu objek.

\section{B. Kompetensi Lulusan PAI}

1. Kompetensi Utama

Secara umum kompetensi lulusan PAI untuk tingkat pendidikan tinggi sama secara nasional, yakni terbentuknya kemampuan lulusan PAI menjadi guru profesional. Guru PAI Profesional memiliki 4 kompetensi dasar, yakni kompetensi pedagogik, kepribadian, sosial, dan profesional (UU No. 14 Tahun 2005 tentang Guru dan Dosen). Menurut Peraturan Menteri Agama No. 16 Tahun 2010 kompetensi guru PAI meliputi kompetensi pedagogik, kepribadian, sosial, professional dan kepemimpinan (Pasal 16).

Istilah pedagogik diterjemahkan dengan kata ilmu mendidik, dan yang dibahas adalah kemampuan dalam mengasuh dan membesarkan seorang anak. Kompetensi pedagogik digunakan untuk merujuk pada keseluruhan konteks pembelajaran, belajar, dan berbagai kegiatan yang berhubungan dengan hal tersebut. Kompetensi pedagogik 
bertumpu pada kemungkinan pengembangan potensi dasar yang ada dalam tiap diri manusia sebagai makhluk individual, sosial dan moral. Secara lebih sederhana kompetensi pedagogik berarti kemampuan guru dalam mengelola kelas sedemikian rupa agar tujuan pendidikan dapat tercapai, yang didalamnya terdapat banyak hal cakupannya. Peraturan Menteri Pendidikan Nasional Nomor 27 Tahun 2008 dijelaskan tentang kompetensi pedagogik, meliputi (1) Menguasai ilmu pendidikan dan landasan keilmuannya; (2) Mengimplementasikan prinsip-prinsip pendidikan dan proses pembelajaran; (3) Menguasai landasan budaya dalam praksis pendidikan (Direktorat Jenderal Pendidikan Islam Kementerian RI, 2010).

Kompetensi personal mencakup: (1) Penampilan sikap yang positif terhadap tugastugas sebagai guru, dan terhadap keseluruhan situasi pendidikan; (2) Pemahaman, penghayatan, dan penampilan nilai-nilai yang semestinya dimiliki oleh guru, (3) Penampilan upaya untuk menjadikan dirinya sebagai suri teladan bagi para siswanya. Peraturan Menteri Pendidikan Nasional Nomor 27 Tahun 2008, yang masuk kedalam kompetensi personal ini yaitu: beriman dan bertakwa, konsisten dalam menjalankan kehidupan beragama dan toleran, berakhlak mulia dan berbudi pekerti luhur, menghargai dan menjunjung tinggi nilai-nilai kemanusian, individualitas dan kebebasan memilih, menunjukkan integritas dan stabilitas kepribadian yang kuat, menampilkan kinerja berkualitas tinggi.

Kompetensi sosial yaitu kemampuan menyesuaikan diri dengan tuntutan kerja dan lingkungan kerja. Memahami dasar, tujuan, organisasi, dan peran pihak-pihak lain (guru, wali kelas, kepala sekolah, komite sekolah) di lingkungan sekolah. kemampuan beradaptasi terhadap lingkungan terbentuk karena adanya kesadaran sosial yang bisa merasakan keadaan bathiniah orang lain sampai memahami perasaan dan pikirannya.

Sebagai pendidik profesional, guru bukan saja dituntut melaksanakan tugasnya secara profesional, akan tetapi juga harus memiliki pengetahuan dan kemampuan. Guru profesional adalah guru yang melaksanakan tugas keguruan dengan kemampuan tinggi (profisiensi) sebagai sumber kehidupan. Dalam kaitannya profesionalisme guru, setidaknya ada tiga ciri, yaitu (a) Guru yang profesional harus menguasai bidang ilmu pengetahuan yang akan diajarkan dengan baik, benar-benar seorang ahli dibidangnya. Guru selalu meningkatkan dan mengembangkan keilmuannya sesuai dengan perkembangan zaman, (b) Guru yang profesional harus memiliki kemampuan menyampaikan atau mengajarkan ilmu yang dimilikinya kepada siswa secara efektif dan efisien, dengan memiliki ilmu kependidikan, dan (c) Guru yang profesional harus berpegang teguh kepada kode etik profesional sebagaimana disebutkan di atas. Kode etik di sini lebih menekankan pada perlunya memiliki akhlak mulia (Depag. RI., 2005: 11). Kompetensi profesional merupakan kemampuan guru dalam penguasaan materi pelajaran secara luas dan mendalam. Mengerti tujuan proses pembelajaran terhadap materi yang diajarkan dan hasil yang akan didapat. Guru mengampu mata pelajaran yang sesuai dengan kompetensi yang dimilikanya, atau dengan kata lain bekerja secara proporsional. 


\section{Kompetensi Pendukung}

Kompetensi pendukung Jurusan PAI secara nasional dan sesuai standar BAN-PT meliputi kompetensi moral, bahasa, penggunaan teknologi informasi, komunikasi, kerjasama, dan pengembangan diri.

Moral berarti kebiasaan berbuat baik, sebagai lawan dari kebiasaan berbuat buruk. Moral lebihb banyak bersifat praktis. Menurut pandangan ahli filsafat, moral memandang tingkah laku perbuatan manbusia secara local, artinya moral menyatakan ukuran sedangkan yang menjelaskan ukuran itu adalah etika. Dalam pembicaran moral tolak ukur yang digunakan adalah norma-norma yang tumbuh dan berkembang dan berlangsung di masyarakat. Istilah moral senantiasa mengaku kepada baik buruknya perbuatan manusia sebagai manusia. Inti pembicaraan tentang moral adalah menyangkut bidang kehidupan manusia dinilai dari baik buruknya perbutaannya selaku manusia. Norma moral dijadikan sebagai tolak ukur untuk menetapkan betul salahnya sikap dan tindakan manusia, baik buruknya sebagai manusia.

Bahasa adalah sesuatu yang sangat penting bagi kehidupan manusia. Bahasa berarti komunikasi, dan tanpa bahasa seseorang tidak dapat berkomunikasi dengan orang lain. Di jaman globalisasi seperti sekarang, bahasa Inggris seakan sudah menjadi kemampuan wajib yang harus dimiliki oleh pelajar, mahasiswa ataupun para profesional. Karena bahasa Inggris merupakan bahasa internasional yang artinya, dalam berkomunikasi di dunia internasional kita harus menggunakan bahasa Inggris. Tidak menguasai bahasa Inggris berarti tidak dapat berkomunikasi dengan dunia internasional. Selain itu, kebanyakan literatur-literatur berkualitas menggunakan berbahasa Inggris dan belum di terjemahkan kedalam bahasa Indonesia.

Bahasa Inggris merupakan bahasa internasional, dan dijaman globalisasi sekarang kita wajib menggunakan bahasa Inggris. Sudah seharusnya para guru termasuk guru PAI memiliki kemampuan bahasa Inggris agar tidak tertinggal perkembangan ilmu pengetahuan dan teknologi.

Memasuki Abad Teknologi Informasi dan Komunikasi (TIK) sekarang ini sangat dibutuhkan dan pentingnya penggunaan ICT (Information and Communications Teknology) dalam kegiatan pembelajaran. Melalui pemanfaatan TIK kita dapat meningkatkan mutu pendidikan, yaitu dengan cara membuka lebar-lebar terhadap akses ilmu pengetahuan dan penyelenggaraan pendidikan bermutu. Sistem Teknologi Informasi dan Komunikasi memberikan jangkauan yang luas, cepat, efektif, dan efesien terhadap penyebarluasan informasi ke berbagai penjuru dunia. Teknologi informasi berkembang sejalan dengan perkembangan teori dan komunikasi teknologi yang menunjang terhadap praktik kegiatan pembelajaran. Kegiatan pembelajaran merupakan kegiatan yang paling pokok dalam keseluruhan proses pendidikan. Hal ini berarti pencapaian tujuan pendidikan banyak bergantung kepada bagaimana proses pembelajaran dirancang dan dijalankan secara profesional. Setiap kegiatan pembelajaran selalu melibatkan dua pelaku aktif, yaitu guru dan siswa. Guru adalah pencipta kondisi belajar siswa yang didesain 
secara sengaja, sistematis, dan berkesinambungan. Sedangkan siswa sebagai peserta didik merupakan pihak yang menikmati kondisi belajar yang menciptakan guru tersebut. Dengan kata lain untuk pendidikan dan pengembangan guru sangat penting bagi keberhasilan penerapan kurikulum berbasis TIK.

Pengembangan diri bagi guru merupakan hal penting bagi suatu pekerjaan profesional, yang memerlukan suatu keahlian khusus. Karena keahliannya bersifat khusus, guru memiliki peranan yang sangat penting dan strategis dalam kegiatan pembelajaran, yang akan menentukan mutu pendidikan di suatu satuan pendidikan. Oleh karena itu, dalam sistem pendidikan dan pembelajaran dewasa ini kedudukan guru dalam proses pembelajaran di sekolah belum dapat digantikan oleh alat atau mesin secanggih apapun. Keahlian khusus itu pula yang membedakan profesi guru dengan profesi yang lainnya. Dimana "perbedaan pokok antara profesi guru dengan profesi yang lainnya terletak dalam tugas dan tanggung jawabnya. Tugas dan tanggung jawab tersebut erat kaitannya dengan kemampuan-kemampuan yang disyaratkan untuk memangku profesi tersebut. Kemampuan dasar tersebut tidak lain adalah kompetensi guru" (Saud, 2009 : 44).

\section{METODE PENGUMPULAN DATA}

Tulisan ini merupakan hasil penelitian penulis dengan jenis penelitian evaluatif yang berupaya menilai dalam bentuk menggambarkan respon pengguna lulusan Jurusan Pendidikan Agama Islam Fakultas Tarbiyah dan Keguruan UIN Alauddin di Kota Makassar. Sumber informasi adalah para kepala Kepala Sekolah dan Madrasah yang ada di Kota Makassar Sulawesi Selatan.

Pengumpulan data dilakukan dengan menggunakan angket, dengan instrumen berupa daftar pertanyaan yang diberikan kepada para responden untuk dijawab berdasarkan keadaan yang sesungguhnya. Angket yang dimaksud terdiri atas 7 indikator utama, yakni angket terkait: (1) kompetensi utama lulusan PAI (kompetensi paedagogik, kepribadian, social, professional, dan kepemimpinan); (2) kompetensi dalam bidang integritas (etika dan moral); (3) kompetensi dalam bidang bahasa; (4) kompetensi dalam penggunaan teknologi informasi; (5) kompetensi komunikasi; (6) kompetensi kerjasama; (7) kompetensi dalam melakukan pengembangan diri. Jumlah item pertanyaan sebanyak 25 item dengan pilihan jawaban: $\mathrm{A}=$ Sangat Baik; $\mathrm{B}=$ Baik; $\mathrm{C}=$ Kurang Baik; dan $\mathrm{D}=$ Tidak Baik. Keempat jawaban tersebut diolah dalam bentuk angka-angka dengan kategori jawab $A=4 ; B=3 ; C=2 ;$ dan $\mathrm{D}=1$, kemudian dianalisis dengan mencari nilai rerata dengan kategori:

$$
\begin{array}{ll}
3,5 \leq \mathrm{RPL} \leq 4 & =\text { Sangat Baik } \\
2,5 \leq \mathrm{RPL}<3,5 & =\text { Baik } \\
1,5 \leq \mathrm{RPL}<2,5 & =\text { Kurang Baik } \\
\mathrm{RPL}<1,5 & =\text { Tidak Baik } \\
\text { Keterangan: RPL } & =\text { Respon Pengguna Lulusan }
\end{array}
$$




\section{HASIL PENELITIAN}

A. Tanggapan Pihak Pengguna Lulusan Jurusan Pendidikan Agama Islam Fakultas Tarbiyah dan Keguruan UIN Alauddin Makassar dalam Aspek Profesionalisme.

Kemampuan alumni PAI dalam menjalankan tugas profesionalismenya di sekolah dapat dibedakan melalui lima aspek, yakni: (1) kemampuan menerapkan keilmuannya dalam pembelajaran; (2) produktivitas dalam pembelajaran; (3) kemampuan melakukan inovasi pembelajaran; (4) kemampuan menyelesaikan permasalahan pembelajaran; dan (5) tanggap terhadap kebutuhan peserta didik. Hasil olah data menunjukkan nilai rerata sama dengan 3,66 dengan kategori sangat baik.

B. Tanggapan Pihak Pengguna Lulusan Jurusan Pendidikan Agama Islam Fakultas Tarbiyah dan Keguruan UIN Alauddin Makassar dalam Aspek Integritas (Etika dan moral).

Kemampuan alumni PAI dalam menjalankan tugas terkait dengan aspek integritas di sekolah dapat dibedakan melalui empat aspek, yakni: (1) kedisiplinan; (2) kejujuran; (3) motivasi kerja; dan (4) etos kerja. Hasil olah data menunjukkan nilai rerata 3,74 dengan kategori sangat baik.

C. Tanggapan Pihak Pengguna Lulusan Jurusan Pendidikan Agama Islam Fakultas Tarbiyah dan Keguruan UIN Alauddin Makassar dalam Aspek Kemampuan Bahasa. Kemampuan alumni PAI dalam menjalankan tugas terkait dengan aspek kemampuan berbahasa dapat dibedakan melalui dua bentuk, yakni: (1) kemampuan dalam bahasa Arab; dan (2) kemampuan dalam bahasa Inggris. Hasil olah data menunjukkan nilai rerata 2,70 dengan kategori baik.

D. Tanggapan Pihak Pengguna Lulusan Jurusan Pendidikan Agama Islam Fakultas Tarbiyah dan Keguruan UIN Alauddin Makassar dalam aspek penggunaan Teknologi Informasi.

Kemampuan alumni PAI dalam menjalankan tugas terkait dengan kemampuan menggunakan teknologi informasi melalui kegiatan pembelajaran di sekolah dapat dilihat melalui nilai rerata 3,32 dengan kategori baik.

E. Tanggapan Pihak Pengguna Lulusan Jurusan Pendidikan Agama Islam Fakultas Tarbiyah dan Keguruan UIN Alauddin Makassar dalam Aspek Komunikasi.

Kemampuan alumni PAI menjalankan tugas dalam aspek kemampuan berkomunikasi di sekolah dapat dibedakan melalui lima bentuk, yakni kemampuan berkomunikasi kepada: (1) peserta didik; (2) sesama guru; (3) tenaga kependidikan di sekolah; (4) atasan/ kepala sekolah/ madrasah; (5) orantua/ wali peserta didik. Hasil olah data menunjukkan nilai rerata 3,70 dengan kategori sangat baik.

F. Tanggapan Pihak Pengguna Lulusan Jurusan Pendidikan Agama Islam Fakultas Tarbiyah dan Keguruan UIN Alauddin Makassar dalam Aspek Kerjasama Tim.

Kemampuan alumni PAI dalam menjalankan tugas di sekolah dalam aspek kerjasama 
tim dapat dibedakan melalui tiga bentuk, yakni: (1) kemampuan bersosialisasi di lingkungan kerja; (2) keterbukaan dalam kritik/saran; (3) kemampuan kerjasama dalam tim. Hasil olah data menunjukkan nilai rerata 3,61 dengan kategori sangat baik.

G. Tanggapan Pihak Pengguna Lulusan Jurusan Pendidikan Agama Islam Fakultas Tarbiyah dan Keguruan UIN Alauddin Makassar dalam Aspek Pengembangan Diri.

Kemampuan alumni PAI menjalankan tugas dalam aspek kemampuan melakukan pengembangan diri di sekolah dapat dibedakan melalui lima bentuk, yakni: (1) kemampuan memotivasi diri mempelajari hal-hal baru untuk kemajuan lembaga terkait tupoksi; (2) kemampuan mengembangkan diri melalui program PKB; (3) kemampuan mengembangkan diri melalui kegiatan diklat; (4) kemampuan mengembangkan diri melalui kegiatan KKG; (5) kemampuan mengembangkan diri melalui kegiatan MGMP. Hasil olah data menunjukkan nilai rerata 3,49 dengan kategori baik.

\section{KESIMPULAN}

Respon pengguna lulusan Jurusan Pendidikan Agama Islam Fakultas Tarbiyah dan Keguruan UIN Alauddin Makassar dapat dilihat melalui beberapa indikator dengan kategori yang variatif, yakni: sikap profesionalisme alumni Jurusan Pendidikan Agama Islam Fakultas Tarbiyah dan Keguruan UIN Alauddin Makassar termasuk dalam kategori sangat baik dengan nilai 3,66; sikap integritas (etika dan moral) termasuk dalam kategori sangat baik dengan nilai 3,74; kemampuan dalam bahasa termasuk dalam kategori baik dengan nilai 2,70; kemampuan menggunakan teknologi informasi dalam kegiatan pembelajaran termasuk dalam kategori baik dengan nilai 3,32; kemampuan berkomunikasi termasuk dalam kategori sangat baik dengan nilai 3,70; kemampuan kerjasama tim termasuk dalam kategori sangat baik dengan nilai 3,61; dan kemampuan melakukan pengembangan diri termasuk dalam kategori baik dengan nilai 3,49.

\section{DAFTAR PUSTAKA}

Ahmadi, Abu. Psikologi Sosial. Jakarta: Rineka Cipta, 1999.

Direktorat Jendral Kelembagaan Agama Islam, Wawasan; Tugas Guru dan Tenaga Kependidikan. Jakarta: DEPAG, 2005.

Kartono, Kartini. Psikology Umum. Bandung: Mandar Maju, 1990.

Kementerian Agama RI, Peraturan Menteri Agama Republik Indonesia Nomor 16 Tahun 2010 tentang Pengelolaan Pendidikan Agama Pada Sekolah. 
Kementerian Agama Republik Indonesia. Peraturan Menteri Agama Nomor 16 Tahun 2010 tentang Pengelolaan Pendidikan Agama pada Sekolah.

Republik Indonesia. Penjelasan atas Undang-Undang Republik Indonesia Nomor Nomor 14 Tahun 2005 tentang Guru dan Dosen. . Undang-Undang Republik Indonesia Nomor 14 Tahun 2005 tentang Guru dan Dosen.

Ritzen, George - Douglas J. Goodman. Teori-Sosiologi Kontemporer, Jakarta, Kencana Lenada Media Group, 2003.

Saud, Udin Syaefuddin. Pengembangan Profesi Guru. Bandung: Alfabeta, 2009.

Soekanto, Soerjono. Sosiologi suatu Pengantar. Jakarta: Raja Grafindo, 1993.

Susanto, Astrid A. Komunikasi Dalam Teori dan Praktek. Bandung: Bina Cipta, 1988. 